\title{
STATELESSNESS DETERMINATION PROCEDURES: TOWARDS A BESPOKE PROCEDURE FOR NIGERIA
}

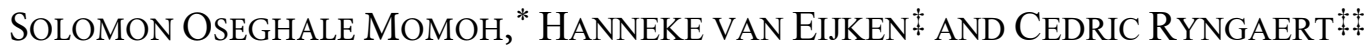

Statelessness is a phenomenon that affects every region and almost every country of the world. However, not very many states have mechanisms in place to identify and prevent it, and protect stateless persons. This article ascertains international norms and best practices regarding the establishment and operation of a Statelessness Determination Procedure ('SDP'), and to apply these to a future SDP in Nigeria. The requirements for an SDP are drawn from conventions, United Nations High Commissioner for Refugees instruments and state practice. In proposing an SDP for Nigeria, in this contribution we strive for the most extensive protection for stateless persons, while taking the particular legal and institutional framework of Nigeria into account. We conclude that Nigeria, and in fact any state, may want to devote particular attention to standards relating to the legality and 'bindingness' of the proposed SDP, to procedural access and to procedural guarantees.

\section{TABLE OF CONTENTS}

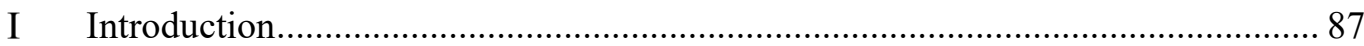

II Statelessness Determination Procedures: Definition and Purpose......................... 88

III Standards and Criteria for a Good Statelessness Determination Procedures.......... 91

A Legality and Binding Nature of SDP ....................................................... 92

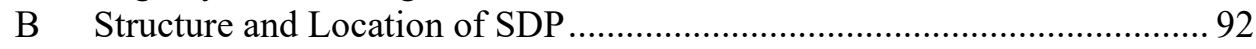

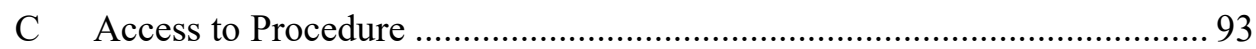



E Assessment of Evidence and Establishment of Fact................................... 95

1 Burden of Proof........................................................................ 96

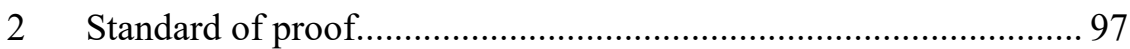

F Management of Combined Refugee and Statelessness Claims .................. 98

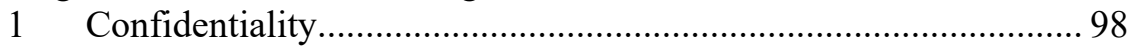

2 Setting up a Combined Determination Procedure ........................... 99

G Prospect for Protection and Naturalisation................................................ 99

H Review and Appeal of Decisions......................................................... 100

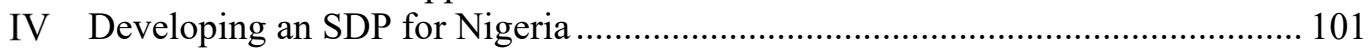

A Current Legal Framework ….................................................................... 101

B Proposed Structure and Location of SDP ................................................ 103

C Proposed Access to Procedure........................................................ 104

D Proposed Procedural Guarantees ................................................................ 105

E Proposed Method for Assessment of Evidence and

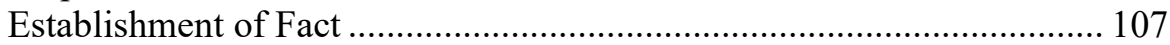

F Management of Combined Refugee and Statelessness Claims ............... 107

G Prospect of Protection and Naturalisation .............................................. 108

$\mathrm{H} \quad$ Proposed Review and Appeal of Decisions.............................................. 109

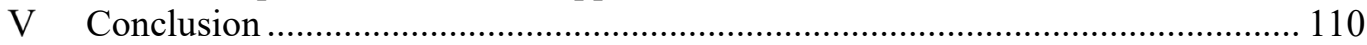

* PhD Researcher, Public International Law, Utrecht University, RENFORCE Research Programme.

* Assistant Professor of EU law, RENFORCE and UCERF research programmes.

\$t Professor of Public International Law, Utrecht University, RENFORCE research programme. The opinions expressed in this article are those of the authors. They do not purport to reflect the opinions or views of the UNHCR. 


\section{INTRODUCTION}

Statelessness affects every region of the world. After decades of neglect, several countries have introduced legal regimes specifically designed to identify and protect stateless persons in recent years. Especially since 2010, an accelerating proliferation of so-called statelessness-specific protection regimes can be witnessed, particularly in Europe and the Americas. ${ }^{1}$ These two regions are leading the way with respect to the identification, prevention and eradication of statelessness. Other states and regions may want to learn from them. Indeed, in many other states across the world, especially in Africa, there are virtually no statelessness determination procedures ('SDP'), whether of an administrative or judicial nature. ${ }^{2}$

The aim of this article is to identify international norms and best practices regarding the establishment and operation of an SDP, and to apply these to a future SDP in Nigeria. When proposing an SDP for Nigeria, we strive for the most extensive protection for stateless persons, while taking the particular legal and institutional framework of Nigeria into account. Nigeria is chosen as a case study as it currently lacks a specific procedure for the protection, identification and prevention of statelessness, although it has recently pledged to develop an SDP. ${ }^{3}$ The development of such a procedure is urgent, as a sizable number of persons in Nigeria are at risk of statelessness, ${ }^{4}$ mainly undocumented border populations. This includes notably the Bakassi population, which was affected by the cession of a part of Nigeria (Bakassi) to Cameroon in the wake of a judgment of the

1 Relevant European countries include Bulgaria, France, Georgia, Hungary, Italy, Latvia, Kosovo, Moldova, Spain, Turkey, and the United Kingdom. Countries in the Americas include Argentina, Brazil, Costa Rica, Ecuador, Mexico, Paraguay, Panama, Peru, and Uruguay. See, eg, Gábor Gyulai, 'Amicus Curiae Submitted by the European Network on Statelessness to the Borgating Court of Appeal in Norway', Submission in Case Number 17073503ASD-BORG/01, Borgating Court of Appeal 25 May 2018, 2-3. See also Noémi Radnai, 'Statelessness Determination in Europe: Towards the Implementation of Regionally Harmonised National SDPs' (Statelessness Working Paper No 2017/8, $5^{\text {th }}$ ed, Institute of Statelessness and Inclusion, December 2017) 6; Gábor Gyulai, 'General Framework and State Practice' (Presentation on Statelessness for the Serbian Government Delegation, UNHCR Regional Representation for Central Europe, 4 November 2014); Katia Bianchini, 'A Comparative Analysis of Statelessness Determination Procedures in 10 EU States' (2017) 29 International Journal of Refugee Law 42, 43.

2 Many African states like Nigeria have neither conducted mapping on statelessness nor have mechanisms to identify stateless persons within their territories. Therefore, the current estimated figure of about 10 million stateless persons worldwide by UNHCR may just be half of the actual number. No country in Africa has a statelessness determination procedure ('SDP') in place at the moment, but this is gradually changing with the recent initiatives by the Economic Community of West African States ('ECOWAS') and the African Union ('AU'). At the time of writing, the AU is on the verge of finalising a 'Draft Protocol' to the African Charter on Human and Peoples' Rights on the 'Specific Aspects on the Right to a Nationality and the Eradication of Statelessness in Africa'. This Draft Protocol is largely influenced by the ECOWAS Abidjan Declaration of 2015, wherein state members committed 'to prevent and reduce statelessness by reforming constitutional, legislative and institutional regimes related to nationality' and called 'upon the African Union to prepare and adopt a protocol to the African Charter on Human and Peoples' Rights on the right to nationality', see Abidjan Declaration of Ministers of ECOWAS Member States on Eradication of Statelessness (25 February 2015).

3 'Results of the High-Level Segment on Statelessness', UNHCR (Web Page, October 2019), $<$ https://www.unhcr.org/ibelong/results-of-the-high-level-segment-on-statelessness/>.

4 Due to the absence of a legal framework in Nigeria, there is no official record of people who are stateless or at risk of statelessness in Nigeria. 
International Court of Justice. ${ }^{5}$ It also includes the Almajiri, ie, children sent to study Islamic education with Islamic scholars right from their childhood and with no records of birth, ${ }^{6}$ undocumented nomads who move from one place or country to another, ${ }^{7}$ internally displaced persons and border populations with no means of identification. ${ }^{8}$ For the identification of the normative framework, we draw the relevant standards from international law, the practice of states and practices recommended by the United Nations High Commissioner for Refugees ('UNHCR'). Pertinent UNHCR documents include in particular the UNHCR Global Action Plan to End Statelessness 2014-2024, ${ }^{9}$ the resultant UNHCR Good Practice Papers on protection, identification, and prevention of statelessness, ${ }^{10}$ and guidelines offered by the UNHCR Handbook on the Protection of Stateless Persons ('UNHCR Statelessness Handbook'). ${ }^{11}$ These standards could roughly be divided into the following categories: protection, avoidance and identification. ${ }^{12}$

In terms of structure, this article sets out to define the concept of SDP (Part II), map international standards that may guide states in establishing an SDP and develop criteria through which the practices in states with existing procedures can be assessed (Part III). Subsequently, these standards and criteria are applied to the situation in Nigeria (Part IV).

\section{Statelessness Determination Procedures: Definition And Purpose}

An SDP could be defined as a procedure, whether administrative or judicial, meant to determine whether or not a person or a population is considered as national of any state under the operation of its law, ${ }^{13}$ with a view to finding durable solutions

5 See Land and Maritime Boundary between Cameroon and Nigeria (Cameroon v Nigeria: Equatorial Guinea Intervening) (Judgment) [2002] ICJ Rep 303.

6 Bronwen Manby, Nationality, Migration and Statelessness in West Africa - A Study for UNHCR and IOM (Report, June 2015) 78.

7 ibid 70.

$8 \quad$ Nigeria Situation 2017 (Supplementary Appeal, UNHCR July 2017) 8.

9 Global Action Plan to End Statelessness 2014-2024 (UNHCR 2014) $<$ https://www.unhcr.org/en-au/protection/statelessness/54621bf49/global-action-plan-endstatelessness-2014-2024.html> ('UNHCR Global Action Plan'). The ten Global Action Points agreed with state parties are: Action 1: Resolve existing major situations of statelessness. Action 2: Ensure that no child is born stateless. Action 3: Remove gender discrimination from nationality laws. Action 4: Prevent denial, loss or deprivation of nationality on discriminatory grounds. Action 5: Prevent statelessness in cases of State succession. Action 6: Grant protection status to stateless migrants and facilitate their naturalisation. Action 7: Ensure birth registration for the prevention of statelessness. Action 8: Issue nationality documentation to those with entitlement to it. Action 9: Accede to the UN statelessness conventions. Action 10: Improve quantitative and qualitative data on stateless populations.

10 UNHCR, Ending Statelessness (Global Appeal 2016-17, 1 December 2015).

'[I]n 2015 UNHCR launched a series of good practice papers, each of which corresponds to one of the 10 Actions in the Global Action Plan [to end statelessness by 2024]. Each paper highlights examples of how States, UNHCR and other stakeholders have addressed statelessness in a number of countries':

See also 'Statelessness', Refworld (Web Page) $<$ https://www.refworld.org/statelessness.html>.

11 Handbook on Protection of Stateless Persons under the 1954 Convention on Relating to the Status of Stateless Persons (UNHCR 2014) ('Handbook on Protection of Stateless Persons').

12 Katja Swider and Maarten den Heijer, 'Why Union Law Can and Should Protect Stateless Persons’ (2017) 19 European Journal of Migration and Law 101, 106.

13 See Convention Relating to the Status of Stateless Persons, opened for signature 28 September 1954, 360 UNTS 117 (entered into force 6 June 1960) art 1 ('1954 Convention'). 
for the affected person or population. The solutions after recognition as a stateless person may range from a grant of protection status to an outright grant of nationality. 14

The Universal Declaration of Human Rights ('UDHR') affirms that 'everyone has the right to a nationality', thereby acknowledging the legal and practical importance of nationality for the enjoyment of human rights. ${ }^{15}$ By virtue of art 15 of the $U D H R$, in addition to the obligations to protect, identify and prevent statelessness, governments must also ensure the eradication of statelessness by ensuring that everyone holds a nationality, ${ }^{16}$ including from birth. ${ }^{17}$ The enjoyment of the right to a nationality serves as a gateway to the enjoyment of other fundamental rights, such as residency rights, health care, free movement, education, family life and political rights. Indeed, not having a nationality creates a legal barrier to enjoy fundamental civil, political, economic, cultural and social rights that most people take for granted. ${ }^{18}$ Thus, it is important that states identify stateless people in their territory so that they can enjoy basic human rights, allowing them to live in dignity until their situation can be resolved through acquisition of a nationality. ${ }^{19}$ Protection in a statelessness context, in its broadest sense, means that a stateless person has access to and can enjoy the rights enshrined in the 1954 Convention Relating to the Status of Stateless Persons ('1954 Convention') and in other relevant international human rights instruments. Protection also means, in a narrower sense, official recognition as a stateless person and being granted a legal status that ensures the proper enjoyment of the abovementioned rights. ${ }^{20}$

SDP involves first identifying all states with which an individual has ties, such as through birth, filiation, marriage or habitual residence, and then determining whether any of those identified states considers the individual as a national, either as a matter of law or as a matter of practice. ${ }^{21}$ The foregoing should be done with a view to acknowledging a person as stateless and where the circumstances or findings suggest so, to subsequently grant protection and to facilitate naturalisation for stateless persons.

14 A recognition of statelessness through SDP should automatically grant protection status that would cumulate into naturalisation eventually, especially for those in migratory context. Otherwise, the SDP would not have fulfilled the obligation under the 1954 Convention arts 3-32. Additionally, in situ population and longstanding residence should be able to immediately access naturalisation.

15 Universal Declaration of Human Rights, GA Res 217A (III), UN GAOR, UN Doc A/810 (10 December 1948) art 15 ('UDHR').

16 See Protecting the Rights of Stateless Persons: The 1954 Convention Relating to the Status of Stateless Persons (Appeal, UNHCR January 2014) 2.

17 See Convention on the Rights of the Child, opened for signature 20 November 1989, 1577 UNTS 3 (entered into force 2 September 1990) art 24(3) ('CRC').

18 Katalin Berényi, 'An Inspiring Parallel between the Italian and Hungarian Jurisprudence with a View to Reducing Statelessness' (2019) 39 DPCE Online 1579.

19 Statelessness Determination Procedures: Identifying and Protecting Stateless Persons (Appeal, UNHCR August 2014) 1 ('Statelessness Determination Procedures') .

20 Gábor Gyulai, 'The Determination of Statelessness and the Establishment of a StatelessnessSpecific Protection Regime' in Alice Edwards and Laura van Waas (eds), Nationality and Statelessness under International Law (Cambridge University Press 2014) 116, 117. This research focuses mainly on the recognition of statelessness through an SDP, as Nigeria has no SDP in place at the moment. However, Nigeria is also advised to take further step in addition to an SDP, to ensure that recognised stateless persons enjoy a legal status that enables them to enjoy rights.

21 Mirna Adjami, Statelessness and Nationality in Côte d'Ivoire - A Study for UNHCR (Report, UNHCR 2006) 41. 
The absence of a dedicated SDP entails a serious risk that stateless persons are not properly identified as such. Without proper identification of stateless persons, it is unclear whether they are accorded appropriate treatment in line with states' obligations pursuant to international treaties. ${ }^{22}$ Furthermore, a determination procedure should ultimately lead to a durable solution for the stateless person, preferably the grant of nationality. States are obliged to ensure facilitated and expedited naturalisation processes for stateless persons. ${ }^{23}$ Recognition as a stateless person is not a substitute for acquisition of nationality. Notably in the case of stateless persons in situ, ${ }^{24}$ where there is a realistic prospect of acquisition of citizenship in the near future, it may be inappropriate to conduct a determination of whether they are stateless, in particular where this could delay a durable solution, ie the grant of nationality. ${ }^{25}$ Depending on the circumstances of the persons under consideration, UNHCR may recommend that states undertake targeted nationality campaigns or nationality verification efforts rather than SDP. ${ }^{26}$ In addition to an SDP, for states where the vast majority of persons do not have any form of national identification to prove their nationality, a nationality verification procedure could be added as an additional layer when an SDP is established.

Although the 1954 Convention remains silent about how to determine who is actually stateless, ${ }^{27}$ a few states have enacted laws establishing formal procedures to this end, including by integrating determination of statelessness into existing administrative procedures. However, many more states are confronted with situations of statelessness and are increasingly required to make determinations on nationality or statelessness regarding persons on their territory. ${ }^{28}$

Determination procedures should be simple and efficient, building to the extent possible on existing administrative procedures that establish relevant facts. Some state practice has, for instance, integrated determination of statelessness in

22 Gerard-René De Groot, Katja Swider, and Olivier Vonk, Practice and Approach in EU Member States to Prevent and End Statelessness (Report, European Parliament 2015) 53.

23 See 1954 Convention (n 13) art 32.

24 In situ statelessness refers to[a person who, or population that, has lived in a particular country for many generations without acquiring the nationality of that country. It could also include person or population who have been arbitrarily deprived of their previous nationality, or persons who have lived most of their lives in a country, without having any tie to any other state, even if their ancestors have not lived in the country for generations. The population basically see the country as their own country, but the authorities do not recognise their claim to such nationality, eg, the situation of many foreigners (mainly of Burkina Faso, Mali and Guinea origin) in Ivory Coast who during colonial times and in the 1960s arrived Ivory Coast to work in Cocoa farms and did not acquire Ivorian nationality when the country gained independence. See also, 'The Lost Children of Côte d'Ivoire', UNHCR (Web Page) $<$ https://www.unhcr.org/ibelong/the-lost-children-of-cote-divoire/>. Another example is the Rohingya population in Myanmar, who for generations have been unable to acquire nationality due to systematic discrimination of Government authorities.

25 UNHCR, Expert Meeting: Statelessness Determination Procedures and the Status of Stateless Persons - Summary Conclusions (Geneva, Switzerland, 6-7 December 2010) 2-3 [2] ('Geneva Conclusions').

26 Handbook on Protection of Stateless Persons (n 11) 26 [58].

271954 Convention (n 13) art 32. See also Gábor Gyulai, Statelessness Determination and the Protection Status of Stateless Persons: A Summary Guide of Good Practices and Factors to Consider When Designing National Determination and Protection Mechanisms (Guidelines, European Network of Statelessness 2013) 5 ('Statelessness Determination and the Protection Status of Stateless Persons').

28 Statelessness Determination Procedures (n 19) 1. 
procedures regulating residency rights. ${ }^{29}$ Factors to consider in setting up a procedure include administrative capacity, existing expertise on statelessness matters, as well as expected size and profile of the stateless population. In any combined procedure, it is essential that the definition of a stateless person is clearly understood and properly applied by case officers and that procedural safeguards and evidentiary standards are respected. ${ }^{30}$

\section{StANDARDS AND CRITERIA FOR A GOOD STATELESSNESS DETERMINATION}

\section{PROCEDURES}

This Part lays out essential requirements for an SDP, drawing mainly from the UNHCR Statelessness Handbook, ${ }^{31}$ reports and the summary of conclusions of the UNHCR expert meetings on SDP, ${ }^{32}$ UNHCR guidelines on statelessness, ${ }^{33}$ and the two Statelessness Conventions, ${ }^{34}$ among other sources.

These standards pertain to the presence of a mechanism for protection, prevention and identification of statelessness, and will be measured against specific criteria of: (a) legality and binding nature of SDP; (b) structure and location of SDP; (c) access to procedure; (d) procedural guarantees; (e) assessments of facts; (f) management of combined refugee and stateliness claims; (g) prospect for naturalisation; and $(\mathrm{h})$ review and appeal of decision. The procedural guarantees and assessment of evidence will be examined in the context of the right to interview, right to an interpreter, right to legal aid, right to individual application for family members (where necessary), right to appeal and review of decision, absence of the requirement of legal residency as a basis for recognition of statelessness, length of procedure, possibility of ex officio application, and the standard and burden of proof.

29 Commemorating the Refugee and Statelessness Conventions - A Compilation of Summary Conclusions from UNHCR's Expert Meetings (Summary Conclusions, UNHCR May 2012) 25 [3] ('Commemorating the Refugee and Statelessness Conventions').

30 Handbook on Protection of Stateless Persons (n 11) 27 [64].

31 ibid.

32 Geneva Conclusions (n 25); UNHCR, Expert Meeting: Interpreting the 1961 Statelessness Convention and Avoiding Statelessness resulting from Loss and Deprivation of Nationality Summary Conclusions (Dakar, Senegal, March 2014); Commemorating the Refugee and Statelessness Conventions (n 29).

33 UNHCR publishes a set of guidelines on statelessness on different themes, especially on the 10 action points: UNHCR Global Action Plan (n 9).

341954 Convention (n 13); Convention on the Reduction of Statelessness, opened for signature 30 August 1961, 989 UNTS 175 (entered into force 13 December 1975) ('1961 Convention’). 


\section{A Legality and Binding Nature of SDP}

While the 1954 Convention, ${ }^{35}$ and other relevant conventions, ${ }^{36}$ do not prescribe a particular procedure for SDP, as a good practice standard it is recommended by the UNHCR that states ensure that a determination procedure is formalised in law, as this will ensure fairness, transparency and efficiency of the process. ${ }^{37} \mathrm{~A}$ state is free to design its own SDP as long as it adheres to the provisions of the 1954 Convention.

Apart from the requirement of having an SDP enshrined in law, one of the very essential requirements of a good SDP, is that the decisions of the determination body be recognised and be considered as binding on other institutions in the state. An SDP should not just be an institutional policy of the agency saddled with a statelessness determination mandate; rather every institution within the state must be bound by the decision of the statelessness determination agency. For instance, institutions that render services within the state should allow recognised stateless persons access to basic services. Stateless persons should be able to access healthcare and other essential services, and the education board should allow recognised stateless persons access to education. Similarly, the immigration authority, the police and other relevant agencies of government must recognise that stateless persons or persons undergoing a determination procedure should not be subject to deportation. In the same vein, if the agency responsible for the granting of a residence permit and naturalisation is separate from the agency that grants statelessness status, the former should be bound by the decision of the latter and grant the required permit, which should in the long run result in naturalisation.

\section{B Structure and Location of SDP}

Where to situate SDP institutionally is a matter of state discretion and can vary from one country to the next. ${ }^{38}$ Current state practice is varied with respect to the location of statelessness determination procedures within the national administrative structures, reflecting country-specific considerations. ${ }^{39}$ States may choose between a centralised procedure or one that is conducted by local authorities. Centralised procedures are preferable as they are more likely to develop the necessary expertise among the officials undertaking status

351954 Convention (n 13).

36 See especially Protocol Relating to a Certain Case of Statelessness, signed 12 April 1930, 179 LNTS 115 (entered into force 1 July 1937); UDHR (n 15); Convention Relating to the Status of Refugees, opened for signature 28 July 1951, 189 UNTS 150 (entered into force 22 April 1954) ('1951 Refugee Convention'); 1961 Convention (n 34); 1954 Convention (n 13); Convention on the Reduction of Statelessness, opened for signature 30 August 1961, 989 UNTS 175 (entered into force 13 December 1975); Convention on the Nationality of Married Women, opened for signature 20 February 1957, 309 UNTS 65 (entered into force 11 August 1958); Convention on the Elimination of All Forms of Discrimination against Women, opened for signature 18 December 1979, 1249 UNTS 13 (entered into force 3 September 1981); CRC (n 17); International Convention on the Protection of the Rights of All Migrant Workers and Members of Their Families, opened for signature 18 December 1990, 2220 UNTS 3 (entered into force 1 July 2003).

37 See Statelessness Determination Procedures (n 19) 5.

38 Good Practices Paper - Action 6: Establishing Statelessness Determination Procedures to Protect Stateless Persons (Good Practices Paper, UNHCR 11 July 2016) 4 ('Good Practices Paper - Action 6').

39 Location in this context means the presence of an SDP either in a central authority or various government agencies across the country. 
determination. ${ }^{40}$ A centralised procedure could be necessary in ensuring the same standards across a country.

While a centralised system may be preferred, due consideration should be given to the need to have a certain balance between centralising expertise to conduct statelessness determination within a specialised administrative or judicial unit of trained and experienced officials, and allowing individuals to lodge applications with government representatives who might be spread out across the country. ${ }^{41}$ This flexibility is particularly necessary in many poor countries in Africa, given the challenging context: these countries are large, and tend to have a weak national road and travel infrastructure, and poor standards of living. Allowing applications to be submitted through specialised agencies at local administrative levels spread across the country would be a preferred method.

Government officials might encounter the question of whether a person is stateless in a range of contexts, reflecting the critical role that nationality plays in everyday life. For example, consideration of nationality status is relevant when individuals apply for passports or identity documents, seek legal residence or employment in the public sector, want to exercise their voting rights, perform military service or attempt to access government services. The issue of nationality and statelessness may also arise when an individual's right to be in a country is challenged in removal procedures. ${ }^{42}$ Therefore, it is important when designing a procedure to also make provision for the possibility of having some form of referral mechanism and pool of trained staff across relevant government agencies, equipped with knowledge to identify potential stateless persons or persons at risk of statelessness. These staff can help refer such persons to the central body or to the relevant government agency in the local government areas or districts. The design should also allow for officials to present an ex officio application on behalf of applicants when they encounter persons who are stateless or are of undetermined nationality.

\section{Access to Procedure}

According to the UNHCR, for procedures to be fair and efficient, and to ensure that all stateless persons benefit from the implementation of the 1954 Convention, access to the SDP must be guaranteed and should not be subject to time limits. Information on the procedure and counselling services must be available to potential applicants in a language they understand. ${ }^{43}$ Additionally, a good procedure should not impose time limits within which an application must be brought from the date of entry into the territory. Also in asylum systems there is typically neither a limitation of time nor a requirement of legal entry. It would be particularly unfair if stateless persons were caught by a time limit, especially in the migratory context where they may not be aware of such a procedure. Nor should a requirement of legal entry be imposed. ${ }^{44}$ Such a requirement is

$40 \quad$ Handbook on Protection of Stateless Persons (n 11) 27 [63].

41 See Marilyn Achiron and Radha Govil, Nationality and Statelessness Handbook for Parliamentarians $N^{\circ} 22$ ( $2^{\text {nd }}$ ed, Inter-Parliamentary Union and UNHCR 2014) 20.

42 Handbook on Protection of Stateless Persons (n 11) 25 [57].

43 Good Practices Paper - Action 6 (n 38) 5.

44 Note that, protection against penalisation of illegal entry is not mentioned under the 1954 Convention. See also the difference in approach to modes of entry in both the 1951 and 1954 Conventions as highlighted in the UNHCR Handbook on Protection of Stateless Persons (n 11) 46 [127]. 
particularly inequitable given that a lack of nationality denies many stateless persons the very documentation that is necessary to lawfully enter or reside in a state. ${ }^{45}$ In this respect, it is noteworthy that in 2015 the Hungarian Constitutional Court held that the requirement of lawful stay to qualify for statelessness status in the Act II of 2007 on the Entry and Stay of Third-Country Nationals was unconstitutional, and annulled it. 46

\section{Procedural Guarantees}

In order to ensure fairness and efficiency, statelessness determination procedures must ensure basic due process guarantees, including the right to an effective remedy where an application is rejected. ${ }^{47}$ For a good determination procedure in an SDP vested in either an administrative or judicial body, legal aid should also be factored in, considering the complexities faced by applicants as well as caseworkers.

As much as possible, no administrative fees should be levied against stateless persons. Should there be a need for administrative fees, such fees should be reasonable and not act as a deterrent to stateless persons seeking protection. ${ }^{48}$ Information on eligibility criteria, the determination procedure and the rights associated with recognition of statelessness is to be widely disseminated by the authorities in a range of languages, and counselling regarding the procedures is to be provided to all applicants in a language they understand. ${ }^{49}$

A proper procedure should ensure that after an application is received, the applicant is interviewed. Where the applicant does not speak the local language or official language of that state, an interpreter should be provided. ${ }^{50}$ An interpreter should also be provided where a written application is required, especially where the applicant is not well-versed in the official language of the state.

It is also key that a determination procedure takes the circumstances of different groups into consideration. For instance, an agency responsible for the determination of statelessness should ensure special protection for unaccompanied minors and those with mental disabilities requiring a legal guardian. ${ }^{51}$ There is also the need for gender balance amongst SDP caseworkers. This will help to ensure respect for people whose culture does not allow for a woman to be seen alone with a man who is not her husband, and ensure that women are able to discuss their protection concerns freely with caseworkers.

Similar to the practice in refugee status determinations, states must also ensure that applicants are not penalised on grounds of illegal entry and residence in their territory. States should also ensure that applicants are not detained pending the determination of status. A time limit from the date of application to the time for

45 Handbook on Protection of Stateless Persons (n 11) 28 [69].

46 Magyarország Alkotmánybírósága [2015] Case No III /01664/2014 (Constitutional Court of Hungary). Pursuant to the annulment, s 76(1) of the Act was amended to read: 'The procedure for establishing statelessness shall be commenced by an application submitted by an applicant residing in the territory of Hungary to the Aliens Police Authority, which may be submitted orally or in writing by the applicant for recognition as a stateless person.'

47 Geneva Conclusions (n 25) 4 [10].

48 ibid. See also 1954 Convention (n 13) art 32.

49 Handbook on Protection of Stateless Persons (n 11) 29.

50 The interpreter must interpret what the applicant says verbatim and not paraphrase, and the interview transcript must also record everything said by the applicant.

51 See Good Practices Paper - Action 6 (n 38) 14. 
the decision must be specified, and such time limit must be reasonable. Applicants should have a right to the ratio decidendi, ie, the grounds on which a decision on their application was made; this/these ground(s) should be specified in writing. In case of confirmation of status, the stateless person should be guided on the next steps, such as how to process the necessary documentation, residence permit and access to naturalisation.

\section{E Assessment of Evidence and Establishment of Fact}

A statelessness determination procedure requires a mixed assessment of fact and law. Case officers must therefore not only assess the law as it stands on paper, but also the implementation of the law in practice, including the extent to which judicial decisions are respected by government officials. ${ }^{52}$ It is generally up to the applicant to provide documentation from the embassy or consular offices of his/her 'country of origin' - the country of birth or a country that issued a prior travel document - confirming that the individual is not a national. ${ }^{53}$ However, due to the difficulties for applicants, depending on their individual circumstances to provide sufficient facts, legislation and documents in support of their statelessness claim, the case officers are obliged to support the applicants in their quest to present a detailed and coherent case.

Since it would be virtually impossible for an applicant to demonstrate that none of world's [195] states considers him or her to be a national, case officers should also help consider states with which an applicant has a relevant link (for example, birth, descent, marriage or habitual residence). ${ }^{54}$

To achieve this, caseworkers should adopt a collaborative, non-adversarial approach in investigating a person's foreign citizenship. ${ }^{55}$ States should also possess an updated collection of nationality laws and should understand their implementation in practice in order to resolve conflicts of law involving nationality. ${ }^{56}$

The types of evidence that may be relevant can be divided into two categories: evidence relating to the applicant's personal circumstances, and evidence concerning the laws and other circumstances in the country in question. ${ }^{57}$

52 See Jessica George and Rosalind Elphick, Promoting Citizenship and Preventing Statelessness in South Africa: A Practitioner's Guide (Pretoria University Law Press 2014) 47. See also Handbook on Protection of Stateless Persons (n 11) 32 [83].

53 Marilyn Achiron, Nationality and Statelessness: A Handbook for Parliamentarians No 11 (Inter-Parliamentary Union and UNHCR 2005) 20.

54 See Michelle Foster, Jane McAdam and Davina Wadley, 'Part One: The Protection of Stateless Persons in Australian Law - The Rationale for a Statelessness Determination Procedure' (2017) 40 Melbourne University Law Review 401, 451.

55 Mariana Olaizola Rosenblat et al, Good Practices in Nationality Laws for the Prevention and Reduction of Statelessness: Handbook for Parliamentarians No 29 (Inter-Parliamentary Union and UNHCR 2018) 21. See also Handbook on the Protection of Stateless Persons (n 11) 34 [89]-[90].

56 Achiron (n 53) 27.

57 Handbook on Protection of Stateless Persons (n 11) 32 [83].

As for the first, UNHCR guidance provides a detailed list of examples, including the applicant's statements, documentary and testimonial evidence, as well as information provided by other states. As for the second, it should be up-to-date and should be obtained from a variety of reliable sources. The complexity of nationality law and practice in a particular State may justify recourse to expert evidence in some cases.

Gyulai, 'Statelessness Determination and the Protection Status of Stateless Persons' (n 27) $28-29$. 
Caseworkers should be able to distinguish between applicants who show no interest in genuinely co-operating or providing necessary information or evidence, from those who may be unable to provide such evidence because of their particular circumstances, such as limited knowledge of the nationality law of their countries of former habitual residence, absence or loss of relevant documents etc. In such circumstances, where the available information is lacking or inconclusive, the caseworker must assist the applicant by interviewing him, undertaking relevant research and, if necessary, making enquiries with the relevant authorities and organisations. ${ }^{58}$

Enquiries of the authorities of the country of former habitual residence which disclose the applicant's personal details must be done with the written consent of the applicant, but if that consent is denied without good reason (for example, it has already been established that the person's claimed fear of those authorities was not well-founded), it may be inferred that the applicant is not genuinely willing to cooperate and is failing to discharge the burden of proof, taking account of all the available information. 59

Hereafter we address who should bear the burden of proof in SDPs, and what standard of proof applies.

\section{Burden of Proof}

In most jurisdictions, the legal burden of proof rests with the party bringing a claim. ${ }^{60}$ In principle, this would mean that a stateless person bears the burden of proof. It is suggested, however, that, in statelessness determination procedures, the burden of proof be in principle shared, which means that both the applicant and examiner must cooperate to obtain evidence, to establish the facts and ultimately clarify whether an individual comes within the scope of the 1954 Convention. ${ }^{61}$ It is not easy for people to prove that they are stateless. Most of the time, stateless persons have no documents or other evidence to prove that they are not considered a national by any state. In light of this, both the applicant and the determination authority must cooperate to obtain evidence to establish the facts. Authorities undertaking statelessness determination must consider all available evidence, oral or written, regarding an individual claim. This may include the analysis of nationality laws of other countries and how they are applied. ${ }^{62}$

Substantiating statelessness can involve evidentiary challenges. Statelessness is rarely a well-documented situation or status, as there are no state authorities obliged to provide an individual with documentation. Therefore, establishing whether an individual 'is not considered as a national ... under the operation of ... law' may require considering a wide range of legal and factual evidence, ${ }^{63}$ on the part of the caseworkers. It is therefore necessary for the burden of proof to be shared between the applicant and the authorities.

58 See Asylum Policy Instruction: Statelessness and Applications for Leave to Remain (Guidance, Version 2.0, UK Home Office 2016) [4.2].

59 ibid.

60 See Nicola Monaghan, Law of Evidence (Cambridge University Press 2015) 35.

61 Handbook on Protection of Stateless Persons (n 11) 34 [89].

62 Statelessness Determination Procedures (n 19) 5.

63 Katja Swider, 'Protection and Identification of Stateless Persons Through EU Law' (Research Paper No 2014-05, Amsterdam Centre for European Law and Governance July 2014) 5. See also Handbook on Protection of Stateless Persons (n 11) 12-13 [23]-[24]. 
The burden of proof is discharged by the applicant rendering a truthful account of facts relevant to the claim so that, based on the facts, a proper decision may be reached. ${ }^{64}$ A proper procedure should not leave the responsibility of establishing a case solely on the applicant who more often than not is unable to solely prove their statelessness status or absence of a link to any nation.

\section{$2 \quad$ Standard of proof}

'It is well known that the standard of proof in a civil case is proof on the balance of probabilities, and that this means that the party bearing the burden of proof must prove that his case is more probable than not'. ${ }^{65}$ However, as regards statelessness claims, it may suffice for a finding of statelessness, that it is established to a 'reasonable degree' that an individual is not considered as a national by any state under the operation of its law. 66 'The standard of proof may be understood, first, as referring to the caution that must be exercised in making positive findings' ${ }^{67}$ The adjudicator needs to decide if, based on the evidence provided, it is likely that the claim of that applicant is credible. ${ }^{68}$

Lord Kitchin, reiterating the points on standard of proof proffered in the UNHCR Statelessness Handbook, ${ }^{69}$ held in the United Kingdom case of $A S$ (Guinea) $v$ Secretary of State for the Home Department as follows:

[A]s with the burden of proof, the standard of proof or threshold of evidence necessary to determine statelessness must take into consideration the difficulties inherent in proving statelessness, particularly in light of the consequences of incorrectly rejecting an application. Requiring a high standard of proof of statelessness would undermine the object and purpose of the 1954 Convention. States are therefore advised to adopt the same standard of proof as that required in refugee status determinations, namely, a finding of statelessness would be warranted where it is established to a 'reasonable degree' that an individual is not considered as a national by any State under the operation of its law. 70

What then is a reasonable degree desired of an applicant? An applicant could be said to have proven his case to a reasonable degree even when the determination authority is unable to find sufficient evidence of a lack of a nationality link to a particular state. A number of considerations are relevant in this context. Has the applicant made sufficient efforts to present documents supporting his or her case? Where s/he does not have sufficient documents, has the applicant demonstrated sufficiency in approach, behaviour and cooperation with the determination authorities in finding solutions for his predicament? Considering the requirement of a shared burden, where caseworkers are unable to find any information to suggest that the applicant is legally linked to any other state, it may be established to a reasonable degree that he is stateless.

64 Note on Burden and Standard of Proof in Refugee Claims (Note, UNHCR 16 December 1998) 2.

65 Mike Redmayne, 'Standards of Proof in Civil Litigation' (2003) 62 Modern Law Review 167, 167.

66 See Handbook on Protection of Stateless Persons (n 11) 35 [91].

67 Hock Lai Ho, A Philosophy of Evidence Law: Justice in the Search for Truth (Oxford University Press 2008) 173.

68 Note on Burden and Standard of Proof in Refugee Claims (n 64) 2.

69 See Handbook on Protection of Stateless Persons (n 11) 34-35.

70 ibid 34-35 [91], quoted in AS (Guinea) v Secretary of State for the Home Department \& Anor [2018] EWCA Civ 2234, [8] (Lord Kitchin). 
Where an applicant does not cooperate in establishing the facts, for example by deliberately withholding information that could determine his identity, then he may fail to establish to a reasonable degree that he is stateless even if the determination authority is unable to demonstrate clear evidence of a particular nationality. The application can thus be rejected unless the evidence available nevertheless establishes statelessness to a reasonable degree. Such cases need, however, to be distinguished from instances where an applicant is unable, as opposed to unwilling, to produce supporting evidence and/or testimony about his or her personal history. ${ }^{71}$

\section{F Management of Combined Refugee and Statelessness Claims}

There is some overlap between UNHCR's statelessness mandate and its refugee mandate because stateless refugees are protected under the provisions of the 1951 Convention Relating to the Status of Refugees ('1951 Refugee Convention'). When refugee status ceases, individuals may remain stateless and therefore of concern to UNHCR. ${ }^{72}$ The UNHCR Statelessness Handbook advises that when an applicant raises both a refugee and a statelessness claim, it is important that each claim is assessed and that both types of status are explicitly recognised. ${ }^{73}$ This is because protection under the 1951 Refugee Convention generally gives rise to a greater set of rights at the national level than under the 1954 Convention. ${ }^{74}$

Considering that sometimes there could be overlaps between refugee and statelessness claims, states may consider establishing a combined determination procedure for both refugee and statelessness determination. Below we will discuss the challenge of managing the confidentiality requirement in the asylum process in case of a combined procedure, ${ }^{75}$ as well the challenge of setting up a combined procedure.

\section{$1 \quad$ Confidentiality}

In SDP, contact with countries of former habitual residence may be necessary in order to obtain information on the nationality link of the applicant. The practice of contacting other states raises confidentiality concerns, especially in situations of mixed statelessness and refugee claims.

At all times, the confidentiality of the asylum application should be respected. In exceptional circumstances, contact with the country of origin may be justified, but even then, the existence of the asylum application should not be disclosed, ${ }^{76}$ unless it has definitively been concluded that the applicant does not have a wellfounded fear and is neither a refugee nor entitled to a complementary form of protection. ${ }^{77}$ States must ensure that confidentiality requirements for refugees who

71 Handbook on Protection of Stateless Persons (n 11) 35 [93].

72 UNHCR Action to Address Statelessness - A Strategy Note (Report, UNHCR March 2010) 5.

73 See Handbook on Protection of Stateless Persons (n 11) 31 [78].

74 ibid

75 ibid 27 [66].

76 ibid 15 [33]. The reason for nondisclosure of asylum information with an applicant's country of origin/habitual residence is because most times, the agent of persecution is the state. For the safety of the applicant, it is necessary for asylum information not to be disclosed to unauthorised persons.

77 ibid 36 [96]. 
might also be stateless are upheld in statelessness determination procedures. 'Every applicant in [an SDP] is to be informed at the outset of the need to raise refugee-related concerns, should they exist'. ${ }^{78}$

If there is insufficient information to conclude that an individual is stateless without contacting the authorities of a foreign state, refugee status determination ('RSD') shall proceed; 79 in such instance, RSD will be preferred.

\section{Setting up a Combined Determination Procedure}

More often than not, it is likely to be a major challenge to set up combined RSD and SDP systems. This will especially be the case where the systems are centralised (eg in the capital) and the case officers who conduct RSD are the same officers who work on SDP. Having the same case officers work on both procedures may lead to a conflation of asylum criteria, procedures and standards in statelessness procedures. To avoid mix-up of approach, it is more beneficial to have designated officials who work on asylum procedures separate from those who work on SDP. This will also help officials develop proficiency and expertise in their respective areas of specialisation.

For a combined refugee and statelessness claim, case officers from both units can come together to work on the application. Asylum case officers can work to ensure the confidentiality requirement is respected, while SDP case officers work on the nature and facts of the statelessness claim, the nationality law and its application in the applicant's former country of habitual residence, including the applicant's link to any other state.

\section{G Prospect for Protection and Naturalisation}

Where a decision recognising statelessness is made through an SDP, such a status should immediately entitle a stateless person to a permanent residence permit, labour and social security rights, access to basic and essential services, travel documents etc. ${ }^{80}$ In some states with a determination procedure, a positive decision or recognition of statelessness does not necessarily lead to a legal status that permits residence and enjoyment of basic human rights, nor does it necessarily facilitate naturalisation. ${ }^{81}$ It is recalled in this respect that nationality provides people with a sense of identity and is key to full participation in society. ${ }^{82}$ Therefore, recognition as a stateless person should not be used as a substitute for nationality, especially where such recognition of status will not guarantee any legal right.

An SDP should lead from acquisition of certain basic rights to a simplified naturalisation process (which, as much as possible, should be without conditions). In order words, states should establish procedures that lead to a legal status that

\footnotetext{
78 ibid 31 [79].

79 ibid 31-32 [81].

80 See 1954 Convention (n 13) arts 15, 17, 19, 21, 23, 24, 28; Statelessness Handbook (n 11) 49-53 [136], [137], [150].

81 See UNHCR Global Action Plan (n 9) 16.

82 Preventing and Reducing Statelessness - The 1961 Convention on the Reduction of Statelessness (Appeal, UNHCR September 2010) 2.
} 
permits residence and guarantees the enjoyment of basic human rights and facilitates naturalisation for stateless migrants. ${ }^{83}$

States have discretion as to the structure of their SDP and their method of granting nationality. After all, in the Nottebohm case, the International Court of Justice held that

it is for every sovereign state, to settle by its own legislation the rules relating to the acquisition of its nationality, and to confer that nationality by naturalization granted by its own organs in accordance with that legislation. ${ }^{84}$

However, states should ensure that applicants are immediately able, or at least in the foreseeable future, through an expedited proceeding, to acquire nationality. As provided in art 32 of the 1954 Convention, where an administrative fee is necessary for acquisition of nationality, as far as possible, the charges and costs of such proceedings should be reduced for stateless persons. Naturalisation could be simplified by ensuring that barriers to an easy and smooth naturalisation process are removed from nationality laws. This could be done through removal or reduction of naturalisation application fees for stateless persons, removal of the requirement of legal residence, reduction of the number of years of residency to qualify for naturalisation, ${ }^{85}$ and removal of language requirements for stateless persons.

\section{H Review and Appeal of Decisions}

A proper determination procedure should guarantee a right to appeal a firstinstance rejection of an application. Such status determination decisions should be subject to review in accordance with the ordinary system for the administrative and judicial review of administrative acts in that country. The lodging of appeals, whether for administrative or judicial remedies, should suspend the execution of any resolution concerning expulsion. 86

In some states, the courts are the competent authorities for the recognition of statelessness in the first instance. An example is Belgium where the courts are the competent authority for SDP. ${ }^{87}$ Italy has both judicial and administrative procedures. ${ }^{88}$ In states with a judicial procedure, the applicable national court or civil procedure rules are applied for determining statelessness. For such a state, there should be another layer for review or appeal of a first instance decision to a higher court. A state may elect to have a separate administrative or judicial review process for SDP distinct from the ordinary system for administrative or judicial review. Nonetheless, it should ensure that such a review process is independent of

83 See UNHCR Global Action Plan (n 9) 16.

84 Nottebohm (Liechtenstein v Guatemala) (Second Phase) (Judgement) [1955] ICJ Rep 4, 20. See also Convention on Certain Questions Relating to the Conflict of Nationality Laws, opened for signature 12 April 1930, 179 LNTS 89 (entered into force 1 July 1937) art 1.

85 The Republic of Brazil is a good example in this regard, reducing the number of years of residence from four to two for stateless persons, see Decreto $n^{\circ} 9.199$, de 20 de novembro de 2017 [Decree No 9199 of November 20, 2017] (Brazil) art 99 [tr author].

86 See Rosenblat et al (n 55) 21, 35.

87 See Carine Rustom and Quentin Schoonvaere, Mapping Statelessness in Belgium (Report, October 2012) 48, 51. See also Recognition of Stateless Persons (Ad-Hoc Query, European Migration Network 2015) 5; Judicial Code (2007) (Belgium) art 569(1).

88 See EMN Inform - Statelessness in the EU (Report, European Migration Network 5 October 2016) 7 . 
the agency that makes first instance decisions in order to guarantee a free, dispassionate and impartial review process.

Appeals must be possible on both points of fact and law as the possibility exists that there may have been an incorrect assessment of the evidence at first instance level.

Whether an appellate body can substitute its own judgment on eligibility under the 1954 Convention or whether it can merely quash the first instance decision and send the matter back for reconsideration by the determination authority is at the discretion of the state. ${ }^{89}$

Though not provided in the Statelessness Conventions, nor in the UNHCR Statelessness Handbook, we advise against a time limit within which an applicant must file an appeal or request review of a decision. In our opinion, it is advisable to leave open the time within which to appeal a negative decision, as this prevents the door from being shut on stateless persons, or other persons at risk of statelessness who should ordinarily benefit from such guarantees.

\section{DEVELOPING AN SDP FOR NigERIA}

This Part will use the standards and criteria analysed above to propose useful guidance for Nigeria to develop its SDP. Inspiration will also be drawn from countries such as Brazil, France, Moldova, Paraguay and the UK, ${ }^{90}$ which have a more or less appropriate legal framework in place for the protection, identification, and prevention of statelessness. The discussion in this Part is largely based on the structure used in Part III.

\section{A Current Legal Framework}

Nigeria acceded to the 1954 Convention and the 1961 Convention on the Reduction of Statelessness ('1961 Convention') in 2011.91 Despite being the first country to ratify these conventions in the Economic Community of West African States ('ECOWAS') region, Nigeria has not domesticated them so as to give them the force of law amongst the laws of the Federation of the Nigerian State. Accordingly, Nigeria currently does not have a legal framework for the

89 Handbook on Protection of Stateless Persons (n 11) 30 [77].

90 In addition to the above mentioned standards, these states have been selected because of their compliance with the criteria mentioned in the introductory part of Part IV above, such as legality and binding nature of their SDP, structure and location of SDP, access to procedure, procedural guarantees, method of assessments of facts, management of combined refugee and stateliness claims, prospect for naturalisation, review and appeal of decisions. The United Kingdom SDP system is criticised by scholars especially with regards to its limitations on access to protection, which are arguably not in line with the 1954 Convention (n 11), as well as its extremely low recognition rates as compared to other countries with a functioning SDP: see Johanna Bezzano and Judith Carter, 'Statelessness in Practice: Implementation of the UK Statelessness Application Procedure' (Report, University of Liverpool July 2018) 14, 20, 24 , 30, 42. See also 'The UK's Approach to Statelessness: Need for Fair and Timely Decisions' (Policy Briefing, Asylum Aid September 2016). Nevertheless, the UK is included in this research because of the fact that Nigerian lawmakers, lawyers and scholars easily connect with the UK system. Nigeria and the UK both have a common law system, and their governance systems share some administrative similarities which may be relevant for developing an SDP for Nigeria. It is easier to convince Nigerian lawmakers about systems that work in the UK (and in Europe generally) rather than in Asia or the Americas. This explains why mostly European States have been included in this research.

91 UNHCR, Submission to the Office of the High Commissioner for Human Rights, Compilation Report - Universal Periodic Review: Nigeria (March 2013) 1. 
determination of statelessness. Instead, when confronted with cases of statelessness, it relies on its RSD procedure set out in the National Commission for Refugees, Migrants and Internally Displaced Persons Act ('NCFRMI Act'). ${ }^{92}$ This leads to incorrect decisions, due the confusion between RSD criteria and standards for determining statelessness.

Realising that the NCFRMI Act is not tailored towards protection, identification and prevention of statelessness, the Government of Nigeria, as a result of repeated advocacy and technical support from UNHCR, has taken some steps towards developing a framework on statelessness. In this regard, in 2016, the Government of Nigeria, with the support of UNHCR and other key stakeholders, drafted a National Plan of Action ('NPA') on statelessness. Although this NPA is not yet approved by the Federal Executive Council, it is a step in the right direction for Nigeria, especially as it makes provision for the establishment of a determination procedure for Nigeria. ${ }^{93}$ In October 2019, at the UNHCR High-Level Segment on Statelessness held in Geneva, Nigeria pledged to develop an SDP to identify stateless persons, grant protection status and facilitate appropriate solutions. ${ }^{94}$

In 2015, an application for refugee status case involving a 'Georgian' woman was presented before the Refugee Eligibility Committee in Nigeria. The woman, now in her late 50s, had come to Nigeria in the 1980s, before the collapse of the Soviet Union. At the time she came to Nigeria, the Republic of Georgia was part of the Soviet Union ('USSR'), and all her national documents were Soviet documents. With no SDP in place, her application was brought under the RSD procedure. Thereafter, she was granted refugee status by the RSD Eligibility Committee on the grounds that she had no home country to return to, as the USSR no longer existed, a reason which in fact did not meet the requirements prescribed in the 1951 Refugee Convention. The Eligibility Committee also considered, arguably wrongly, that she was unable to prove her Georgian nationality, and therefore did not recognise her as Georgian. ${ }^{95}$ The outcome of this case would have been different if Nigeria had an SDP in place. Instead of being recognised as a refugee, the woman would have gone through an SDP and be granted statelessness status, which in turn would have facilitated her naturalisation.

In line with international standards, it is recommended that Nigeria take further steps to domesticate the 1954 Convention and the 1961 Convention. In particular, it should develop a determination procedure formalised in law, similar to what it has done with the 1951 Refugee Convention, ${ }^{96}$ as this will ensure fairness,

92 Decree 52 of 1989 (Nigeria). This law is now Chapter 21 of the Laws of the Federation of Nigeria 2004 ('NCFRMI Act').

93 Action 5 of the unpublished draft National Plan of Action ('NPA'), updated in 2018, provides for the establishment of a determination procedure for Nigeria: National Action Plan to End Statelessness - Nigeria (Unpublished, 2018) 15-17 ('NPA'). A copy of the updated plan was obtained and discussed in the course of this research with an official of the Civil Society Legislative Advocacy Centre in June 2019.

94 See 'Results of the High-Level Segment on Statelessness' UNHCR (Web Page, October 2019) $<$ https://www.unhcr.org/ibelong/results-of-the-high-level-segment-on-statelessness/>.

95 This example was cited in an interview with an official of the Refugee Status Determination ('RSD') at the National Commission for Refugees, Migrants and Internally Displaced Persons ('NCFRMI') during the course of this research. We contacted the Official with the aim of finding out if there had been any known statelessness case brought before the Refugee Eligibility Committee in Nigeria.

96 Nigeria domesticated the 1951 Refugee Convention (n 36) and its 1967 Protocol through the NCFRMI Act, wherein the two Conventions were added as annexes. 
transparency and efficiency of the process,${ }^{97}$ as we have argued in Part III. Below, we will outline what an SDP for Nigeria could look like.

\section{B $\quad$ Proposed Structure and Location of SDP}

When proposing a structure and location of SDP for Nigeria, it is important to draw from practices in states with fairly good SDP in place. States that could guide Nigeria in this regard are the UK and Brazil. In the UK, the competent authority for determination of statelessness is the Home Office Department of Visas and Immigration. The Home Office's Department of Visa and Immigration is responsible for considering applications for British citizenship from foreign nationals as well as the determination of statelessness. ${ }^{98}$ Similarly, in Brazil, the National Secretariat of Justice of the Ministry of Justice and Public Security is responsible for matters related to nationality, naturalisation, recognition of refugee status, statelessness, residence permit. 99

In Nigeria, somewhat similarly, the Ministry of Interior ('MOI') is currently responsible, amongst others, for granting Nigerian Citizenship and for immigration services. The MOI has a department known as the Directorate of Citizenship and Business, which is responsible inter alia for expatriate quota administration and matters relating to the grant of Nigerian citizenship. ${ }^{100}$ It also has the responsibility for administering and enforcing the provisions of the Immigration Act, evaluating applications for citizenship by naturalisation, confirmation or registration, granting of Special Immigration Status, granting of a Temporary Residence Permit, granting of Renunciation of Nigerian Citizenship etc. ${ }^{01}$ The Nigeria Immigration Service ('NIS') is a Department under the Ministry of Interior, just like the Department of Visa and Immigration of the UK Home Office.

Unlike the National Secretariat of Justice of Brazil and the UK Department of Visas and Immigration both of which are responsible for both citizenship, asylum and statelessness matters, ${ }^{102}$ the competent agency for asylum matters in Nigeria is the National Commission for Refugees, Migrants and Internally Displaced Persons ('NCFRMI'). ${ }^{103}$ The NCFRMI, through its RSD, determines refugee status in Nigeria, but it is not mandated to handle or grant Nigerian citizenship. This is the preserve of the Ministry of Interior's Directorate of Citizenship and Business.

97 See Statelessness Determination Procedures (n 19) 5.

98 'Apply for Citizenship If You're Stateless', GOV.UK (Web Page) $<$ https://www.gov.uk/apply-citizenship-stateless>.

99 'Migrações' [Migrations], Justica e Segurança Publica [Justice and Public Security] (Web Page) <https://legado.justica.gov.br/seus-direitos/migracoes $>$. The National Secretariat of Justice has a Department of Migration and the National Committee for Refugees ('CONARE').

100 'Citizenship and Business', Ministry of Interior (Web Page) $<\mathrm{https}$ ://interior.gov.ng/citizenship-and-business//>.

101 'NIS Structure', Nigeria Immigration Service (Web Page) < https://immigration.gov.ng/nisstructure/>; 'About C\&B Department', Ministry of Interior (Web Page) $<$ https://www.ecitibiz.interior.gov.ng/home/about $>$.

102 In Brazil, the Department of Migration, which grants access to nationality, is separate from CONARE, but they are both within the National Secretariat of Justice.

103 NCFRMI is under the Ministry of Humanitarian Affairs, while the Citizenship and Business Department that grants access to nationality in Nigeria is under the Ministry of Interior. See 'The Commission', National Commission For Refugees Migrants and Internally Displaced Persons (Web Page) <https://ncfrmi.gov.ng/the-commission/>. 
It is proposed here to place the relevant statelessness determination/verification body within this Directorate, ie, the department responsible for citizenship and naturalisation. This department is the most appropriate body, especially for individuals who may have been in Nigeria for generations, such as an in situ population. ${ }^{104}$ Admittedly, 'best practice' states like France, Moldova and Paraguay may have agencies for statelessness determination that are separate from those that grant nationality, ${ }^{105}$ but this is by no means required. In fact, according to UNHCR, a state is at liberty to locate an SDP within its immigration authorities, or within the body responsible for nationality issues (eg naturalisation applications or verification of nationality requests). ${ }^{106}$ UNHCR has advised that locating an SDP within the latter type of body is particularly appropriate where the individuals concerned are likely to be longstanding residents of the state. ${ }^{107}$

With regards to the precise location of the SDP within the Ministry of Interior, Nigeria may choose a central SDP within the Ministry, or decentralise SDP as appropriate. One should bear in mind, however, that Nigeria is a federal state with 36 component states and 774 Local Governments Areas ('LGA'), in addition to its many Federal and State Ministries, Departments and Agencies ('MDA'). Therefore, as recommended above, Nigeria may want to ensure that its SDP allows for referrals of cases from the component states, LGA, and MDA to the central body for determination of statelessness. The SDP should also allow for crossreferrals between refugee determination procedures and statelessness determination procedures: the NCFRMI can refer potential statelessness cases from its refugee procedure to the statelessness procedure, and vice versa.

\section{Proposed Access to Procedure}

As noted in the previous section, Nigeria has an existing citizenship acquisition procedure through a Directorate at the Ministry of Interior, which would be the appropriate department to locate an SDP. The Ministry of Interior has launched an

104 Citizenship Overview', Ministry of Interior (Web Page) $<$ https://ecitibiz.interior.gov.ng/citizenship/overview>. In general, this department is responsible for any person who may be entitled to Nigerian nationality by confirmation, naturalisation, registration or may be entitled to a residence permit.

105 In France, the French Office for the Protection of Refugees and Stateless Persons ('OFPRA') is responsible for refugee and statelessness matters, while the local Préfectures (towns) are responsible for the granting of French nationality and residence permits. OFPRA and the Préfectures are both departments of the French Ministry of Interior. For more information, see 'Office français de protection des réfugiés et apatrides' [French office for the protection of refugees and stateless persons], OFPRA (Web Page) $<$ https://www.ofpra.gouv.fr/> and 'Préfectures' [Prefectures], Minstere de L'Interieur [Ministry of Interior] (Web Page) $<$ https://www.interieur.gouv.fr/Le-ministere/Prefectures $>$. In Moldova, the Bureau for Migration and Asylum within the Ministry of Internal Affairs is responsible for statelessness and refugee matters, see 'Bureau for Migration and Asylum', Ministry of Internal Affairs (Web Page) <http://bma.gov.md/en>; while the agency responsible for Moldovan nationality and residence permits is the Public Services Agency, see 'Services', Public Services Agency (Web Page) <http://www.asp.gov.md/node/1376>. In Paraguay, 'the National Constitution explicitly recognised the Judicial Power as the institution responsible for citizenship, considering the legal conditions for its acquisition and loss, together with the content of rights for citizens (article 154)': Elisa Brey, Report on Citizenship Law: Paraguay (Technical Report March 2016) 9. CONARE is responsible for statelessness and asylum issues in Paraguay. See Ley $N^{\circ} 6.149$ Proteccion y facildades para la naturalizacion de las personas apatridas [Law No. 6, 149 on Protection and Facilities for the Naturalization of Stateless Persons 2018] (Paraguay) arts 31-32 [tr author] ('Paraguay Statelessness Law').

106 Handbook on Protection of Stateless Persons (n 11) 27 [65].

107 ibid 26 [59], 27 [65]. 
online platform to apply for Nigerian nationality, called eCitiBiz. The eCitiBiz platform is a highly customisable and industry standard organisational operations system designed to electronically capture and pivot all aspects of the operations and work flow of the Directorate of Citizenship and Business. ${ }^{108}$ Similar to the UK's FLR(S) online form to apply for leave to remain as a stateless person in the UK through a UK Government website, ${ }^{109}$ this eCitiBiz could become a tool for individuals to apply for determination as a stateless person, for nationality verification, or for a residence permit. When a determination procedure will be finally adopted, the adjustment that needs to be made to the existing eCitiBiz is to create a provision for application for leave or a permit to remain in Nigeria as a stateless person, and removal of the requirement of application fee for stateless persons.

Additionally, the proposed SDP framework should allow for Nigerian officials to initiate ex officio SDP for stateless persons, as it is done for instance in Moldova, ${ }^{110}$ this would allow for people who would otherwise not be aware of such a procedure, or indigent and uneducated applicants, to be assisted by the State. As argued above, access to the SDP should not be subject to time limits. Also, like in the current refugee status determination procedure, 111 information on the procedure and counselling services should be available to applicants. ${ }^{112}$

Also, considering the history of gender discrimination with regards to access to nationality in Nigeria, ${ }^{113}$ it is important for an SDP for Nigeria to clearly spell out that women shall have access to the procedure and be able to transmit their status where necessary on an equal footing with men.

\section{Proposed Procedural Guarantees}

To understand the procedural guarantees for a possible SDP in Nigeria, in the current absence of an SDP it is important to examine the RSD procedure, ie, the asylum procedure. Examining the current asylum procedure is relevant because, by virtue of Action 5 of the NPA, 114 the NCFRMI, the Government's refugee agency, is inadvertently tipped to be the lead agency for SDP in Nigeria. The agency is also in the process of drafting Standard Operation Procedures ('SOPs') for SDP in Nigeria. It is very likely that the NCFRMI will rely on the existing

108 See 'Citizenship and Business', Ministry of Interior (Web Page) $<$ https://interior.gov.ng/citizenship-and-business/>.

109 'Application to Extend Stay in UK as Stateless Person: Form FLR(S)', GOV.UK (Web Page) $<$ https://www.gov.uk/government/publications/application-to-extend-stay-in-uk-asstateless-person-form-flrs $>$.

110 See Law No 200 of 16.07.2010 on the Regime of Foreigners in the Republic of Moldova (Republic of Moldova) art 871(1). ('Moldova Foreigners Regime'). See above Part III.

111 NCFRMI Act (n 92) pt V.

112 See Good Practices Paper - Action 6 (n 38) 5; NCFRMI Act (n 92); and the suggestion in Part III(D) above.

113 Nigerian women are unable to transmit their nationality to their foreign husbands as Nigerian men would to their foreign wives. Men married to Nigerian women must wait for 15 years before they qualify to apply for naturalisation as opposed to women married to Nigerian men who are almost immediately able to register as Nigerian citizens. See the Constitution of The Federal Republic of Nigeria 1999 (Nigeria) ss 26(2)(a), 27 ('Nigerian Constitution').

114 The NCFRMI was made the focal agency to 'review the existing national framework in order to mandate a State agency responsible for the determination of stateless persons and the protection of stateless persons': NPA (n 93) 16. 
asylum procedure when developing an SDP for Nigeria. ${ }^{115}$ After all, RSD is the procedure that is closest to an SDP.

According to $\mathrm{s} 8$ of the NCFRMI Act, an application for the grant of refugee status could be made on behalf of an applicant by a competent officer or through the office of the UNHCR. ${ }^{116}$ The NCFRMI Act does not specify that the applicant must be interviewed, nor does it guarantee the right to an interpreter and legal aid. ${ }^{117} \mathrm{We}$ would in any event recommend, in accordance with what we earlier suggested in Part III(D), that when drafting an SDP for Nigeria, drawing on the asylum procedure, the following rights be specified in the SDP framework: right to interview, ${ }^{118}$ right to free interpretation in the language of the applicant, ${ }^{119}$ and right to legal aid. ${ }^{120}$ Legal aid should start at the beginning of an SDP application and not commence only at the appeals stage ie the current asylum procedure in Nigeria. It should be clearly stated that no administrative fee will be charged for

115 In addition to pt V of the NCFRMI Act (n 92) on steps to applying for refugee status in Nigeria, the NCFRMI has an unpublished supplementary Standard Operating Procedures ('SOP') on RSD jointly developed by NCFRMI and UNHCR: Standard Operating Procedures for Refugee Status Determination in Nigeria (NCFRMI and UNHCR, 2006) ('Standard Operating Procedures - Nigeria'). A hardcopy of the SOP was retrieved and discussed in the course of this research with an official of the RSD unit at the NCFRMI.

116 NCFRMI Act (n 92) s 8.

117 In practice, UNHCR sponsors legal aid for refugees, as the Government has no provision for it. However, the NCFRMI supplementary SOPs do guarantee the right to an interpreter and legal aid: Standard Operating Procedures - Nigeria (n 115) 8 [2.1](xii), 20 [3.4](iii), 38 [6.1].

118 Interview is compulsory in Moldova, see Moldova Foreigners Regime (n 110) art $87^{3}$. Interview is also compulsory in Paraguay, see Paraguay Statelessness Law (n 105) arts 33(e), 36. However, it is optional in France and the UK. For France, see Code de l'entrée et du séjour des étrangers et du droit d'asile [Code for the Entry and Stay of Foreigners and the right to asylum] (France) art R 812-2 ('CESEDA'); Guide des Procedures a l'OFPRA [Guide to the Procedures of OFPRA] (Policy Guide, OFPRA 2019) 44 $<$ https://www.ofpra.gouv.fr/sites/default/files/atoms/files/guide_des_procedures_a_lofpra_2019.pdf $>$ ('OFPRA Guide'). For the UK, see 'Applications for Leave to $\bar{R}$ emain as a Stateless Person' Home Office (Web Page, 1 May 2013) $<$ https://webarchive.nationalarchives.gov.uk/20131002094719/http://www.ukba.homeoffice .gov.uk/sitecontent/documents/policyandlaw/stateless-guide/statelessguide.pdf?view=Binary $>$.

119 Applicants in Moldova, UK, Paraguay and France get free interpretation. For Moldova, see Moldova Foreigners Regime (n 110) art $87^{1}$. For UK, see Home Office, Stateless Leave $\begin{array}{llllll}\text { Version 3.0. (Policy Guide, } 30 & \text { October 2019) } & 12\end{array}$ $<$ https://assets.publishing.service.gov.uk/government/uploads/system/uploads/attachment_d ata/file/843704/stateless-leave-guidance-v3.0ext.pdf $>$ ('Home Office Stateless Leave'). For France, see CESEDA (n 118) art R.812-2. For Paraguay, see Paraguay Statelessness law (n 105) art 33(e).

120 Legal aid is guaranteed by law in Moldova, see Law No 198 of 26.07.2007 on the Legal Assistance Guaranteed by the State (Republic of Moldova) arts 6, 7. For Paraguay, legal aid is only guaranteed for applicants without financial means, see Paraguay Statelessness Law (n 105) art 38. In the UK and France, there is no such provision. For the UK, see Johanna Bezzano and Judith Carter, Statelessness in Practice: Implementation of the UK Statelessness Application Procedur (University of Liverpool Law Clinic 2018) 7. While for France, legal aid is only available to French nationals and nationals of the member states of the European Union. Foreign nationals habitually and regularly residing in France are also eligible for legal aid. However, legal aid may exceptionally be granted to persons (including stateless persons) who do not fulfil the conditions set out in the law on legal aid, when their situation appears particularly worthy of interest. See Loi $n^{\circ} 91-647$ du 10 juillet 1991 relative à l'aide juridique [Law No 91-647 of July 10, 1991 relating to legal aid] (France) JO, art 3 $<$ https://www.legifrance.gouv.fr/affichTexteArticle.do?cidTexte=JORFTEXT00000053761 1\&idArticle=LEGIARTI000030022902\&dateTexte=\&categorieLien=id $>$. 
an SDP. ${ }^{121}$ Regarding the timeframe within which a decision must be made, it is recommended that Nigeria set a (reasonable) time frame from the date of application to the time for statelessness status decisions. A best practice in this regard is Moldova, where decisions are normally made within 6 months, and exceptionally within 12 months. ${ }^{122}$

It is also important for Nigeria to transpose the practice of non-penalisation of applicants on grounds of illegal entry and residence in its asylum procedure to the proposed SDP (See Part III(E) above). This ensures that applicants are not detained pending the determination of status.

\section{E Proposed Method for Assessment of Evidence and Establishment of Fact}

In the current asylum procedure, in keeping with the UNHCR Handbook on Procedures and Criteria for Determining Refugee Status and Guidelines on International Protection, ${ }^{123}$ the burden of proof is shared between the applicant and the case officer, even if the NCFRMI Act and the refugee procedure SOPs do not explicitly provide for a shared burden. This burden sharing system should be retained in the proposed SDP framework, as we have argued in Part III(E). Nigeria could draw inspiration in this respect from the SDP systems in France, Moldova, and Paraguay, where case officers can collect information from the applicant's place of birth, place of residence, including from state authorities in the last place of habitual residence of the applicant. 124

The standard of proof that is used in RSD in Nigeria is the balance of probabilities. For SDP, we would propose a somewhat lower standard ie proof to a reasonable degree, as recommended by UNHCR, ${ }^{125}$ and in this article in Part III(E).

\section{F Management of Combined Refugee and Statelessness Claims}

As noted earlier, UNHCR advises that when an applicant raises both a refugee and a statelessness claim, it is important that each claim is assessed and that both types of status are explicitly recognised. ${ }^{126}$ UNHCR acknowledges that sometimes there could be overlaps between refugee and statelessness claims, and on that ground advises states to consider establishing a combined procedure for both refugee and statelessness determination. Although we would recommend separate determination procedures as well as different agencies for SDP and asylum procedures (see Part III(F)), if procedures were to be combined in Nigeria, it is imperative that Nigeria examine how to manage confidentiality concerns, especially in situations of mixed statelessness and refugee claims, considering the

121 Although no administrative fee is charged in RSD practice in Nigeria, the NCFRMI Act and its SOPs are silent on it.

122 See Handbook on the Protection of Stateless Persons (n 11) 30 [75]. See also Moldova Foreigners Regime (n 110) art $87^{2}(1)$.

123 Handbook on Procedures and Criteria for Determining Refugee Status and Guidelines on International Protection Under the 1951 Convention and the 1967 Protocol Relating to the Status of Refugees (UNHCR February 2019) 43 [196].

124 See OFPRA Guide (n 118) 55 [9.2]; Moldova Foreigners Regime (n 110) art 872(2); Paraguay Statelessness Law (n 105) art 44.

125 See Handbook on the Protection of Stateless Persons (n 11) 34 [91].

126 ibid 31 [78]. 
extreme confidentiality required in asylum procedures. ${ }^{127}$ An example is the UK, where for confidentiality reasons, the SDP is entirely independent of the asylum procedure. ${ }^{128}$ The UK system allows for the asylum claim to be considered first, and the statelessness claim to be considered only after the asylum claim has been determined or withdrawn.

\section{G Prospect of Protection and Naturalisation}

As discussed earlier, an SDP should lead from acquisition of certain basic rights to a simplified naturalisation process. ${ }^{129}$ This is not the practice in Nigeria at the moment on the basis of its asylum procedure, even if s 17 of the NCFRMI Act in principle allows for refugees to naturalise. The Nigerian Constitution requires that the applicant have resided in Nigeria for at least 15 years before qualifying to apply for naturalisation. ${ }^{130}$ It also imposes other conditions such as that the person must be of 'good character', 131 must make a 'useful contribution'132 to the advancement, progress and well-being of Nigeria, and must be 'acceptable' and 'assimilated into a local community'. ${ }^{133}$ The Nigerian Constitution does not define character and useful contribution, leaving their definition to the discretion of the authorities charged with applying or interpreting these terms.

These requirements do not as such violate international law. However, for stateless persons, it is recommended for them to immediately have access to nationality as a more durable solution for their plight. Arguably, as we advised in Part III(G), an SDP should lead to immediate access to a facilitated or simplified naturalisation process This is similar to the system in Brazil, where a recognised stateless person has access to naturalisation within 30 days of the decision recognising statelessness. ${ }^{134}$ If Nigeria is not disposed to granting access to naturalisation to stateless persons immediately after recognition like it is done in Brazil, as regards temporal conditions for naturalisation, we recommend the French practice. In France, a recognised stateless person obtains access to naturalisation after five years, reduced to two years for foreigners, including stateless persons who successfully complete two years of university education with a diploma conferred by a French university or establishment of higher education. ${ }^{135}$ Recognised stateless persons should however have be immediately

127 As recommended by UNHCR, unless extremely necessary, contact with state authorities should not be made. Where such contacts are made, the existence of an asylum application should not be disclosed: ibid 31 [79], 36 [96].

128 Statelessness in the EU (Report, European Migration Network and INFORM 2016) 7 $<\mathrm{https}$ ://ec.europa.eu/homeaffairs/sites/homeaffairs/files/00_inform_statelessness_final_en.pdf $>$.

129 See UNHCR Global Action Plan (n 9) $1 \overline{6}$.

130 See Nigerian Constitution (n 113) ss 27(2)(i)-(ii).

131 ibid ss 26(1)(a), 27(1)(b).

132 ibid s 27(1)(e).

133 ibid $\mathrm{s} 72(2)(\mathrm{d})$.

134 This person has immediate access to permanent residency. See Lei $N^{\circ} 13.445$, De 24 De Maio De 2017 de Migração [Law No 13.445 of May 24, 2017, The Migration Law] art 26(7)(8) $<$ http://www.planalto.gov.br/ccivil_03/_ato2015-2018/2017/lei/L13445.htm> ('Brazil Migration Law').

135 See Civil Code (France) [tr Georges Rouhette and Anne Rouhette-Berton, The French Civil Code (2006)] arts 21-17, $<$ https://www.legifrance.gouv.fr/content/download/1950/13681/version/3/file/Code_22.pdf> ('French Civil Code'). 
entitled to a permanent residence permit, labour and social security rights, access to basic and essential services, travel document etc, as we argued in Part III(G). ${ }^{136}$

In terms of responsible agencies, Brazil and the UK are recommended as best practices. In these countries, the same agency is responsible for both SDP and naturalisation. ${ }^{137}$ An SDP embedded in the Directorate of Citizenship and Business of the Nigerian Ministry of Interior may thus create a pathway from determination of statelessness status to acquisition of nationality.

\section{H Proposed Review and Appeal of Decisions}

Section 8 of the NCFRMI Act guarantees the right to an effective remedy where an application for a grant of refugee status is rejected, by providing that the applicant may appeal against the decision of the Eligibility Committee to the Refugee Appeal Board. This is a good practice that should be retained when an SDP is developed in Nigeria. Still, we have some doubts regarding the requirement in the NCFRMI Act that the applicant should appeal within 30 days of being notified of the refusal. While such a time limit does not as such violate international law, ${ }^{138}$ as argued in Part III(H), we advise to leave open the time within which to appeal a negative decision.

As far as administrative review is concerned, it is of note that Nigeria has an Advisory Committee on Nigerian Citizenship ('ACNC'), ${ }^{139}$ which reviews applications and decisions of the Ministry of Interior and makes recommendations for grant or refusal of Nigerian nationality. What is not clear, however, is the extent to which the ACNC reviews the decisions of the Ministry. If the ACNC actually reviews the decisions of the Ministry, then this could be adapted when a

136 See 1954 Convention (n 13) arts 15, 17, 19, 21, 23, 24, 28; Handbook on the Protection of Stateless Persons (n 11) 49 [136]-[137], 53 [150]. For Brazil, see Brazil Migration Law (n 134) art 26. For France, see CESEDA (n 118) arts L.313-1, L.313-26, L.812-7, L380-1 and French Civil Code (n135) art 21-17. For Moldova, see Moldova Foreigners Regime (n 110) arts 4, 877(3). For Paraguay, see Paraguay Statelessness Law (n 118) arts 23-28. For UK, see Immigration Act 1971 (UK) s 3(1)(c); Housing Act 1996 (UK) pts 6, 7; Immigration Rules 1994 (UK) pt 14, rr 405, 410-16 ('UK Immigration Rules'). Note that, in the UK, permanent residency is only granted to a person who has had leave to remain as a stateless person for at least five years. In France, the resident permit issued is not a permanent residence permit (renewable). However, stateless persons have access to naturalisation after five years of legal residence.

137 See Brazil's National Secretariat of Justice website via 'Migrações', [Migrations] Justica e Segurança Publica [Justice and Public Security] (Web Page) $<$ https://legado.justica.gov.br/seus-direitos/migracoes>; Home Office Stateless Leave (n 119); Guide AN Naturalisation Booklet - The Requirements (Policy Guide, Home Office March 2019)

$<$ https://assets.publishing.service.gov.uk/government/uploads/system/uploads/attachment d ata/file/794168/Guide_AN_Naturalisation_Booklet.pdf $>$; and 'Citizenship and living in the UK’, GOV.UK (Web Page)<https://www.gov.uk/browse/citizenship/citizenship>.

138 See NCFRMI Act (n 92) art 8(7) and Law of the Republic of Moldova, Administrative Court Act (Moldova) [2000] No 793-XIV, art 17(1) both of which provides for 30-day appeal period, while for France it is within months. For more information see 'Apatridie: Les voies de recours', Office français de protection des réfugiés et apatrides [French Office for the Protection of Refugees and Stateless Persons] (Web Page) $<$ https://www.ofpra.gouv.fr/fr/apatridie/les-voies-de-recours $>$. The international law instruments such as the 1951 Refugee Convention (n 36) art 31(2) on appeal; the 1954 Convention (n 13), and the Handbook on the Protection of Stateless Persons (n 11) 19 [47] on appeal/review did impose a specific time frame for submission of appeal applications.

139 See, E I Nwogugu, 'Recent Changes in Nigerian Nationality and Citizenship Law' (1976) 25 International and Comparative Law Quarterly 423, 434. 
determination procedure is finally established. Like in the UK, ${ }^{140}$ applications for administrative review of negative decisions regarding statelessness determinations could be sent to the ACNC. The problems with such a system, however, are that administrative review committees, such as the ACNC, usually only look into the procedural correctness of a decision, and, moreover, do not reverse decisions: they only make recommendations to the responsible agency. Appeals, however, usually lead to a reversal of earlier decisions if the procedures where not properly applied. ${ }^{141}$

We would therefore recommend the system in Moldova, where SDP appeals go to regular courts. ${ }^{142}$ In the case of Nigeria, we would specifically recommend the Federal High Court, as the court with constitutional power to entertain matters concerning citizenship and naturalisation, ${ }^{143}$ or alternatively, the establishment of a special Administrative Court, as France has done. ${ }^{144}$ However, the French Administrative Court's decision has no suspensive effect, which means that, if the foreigner is the addressee of a deportation order, the administration can carry it out, even if the Administrative Court has not yet decided on the appeal. ${ }^{145}$ Whatever approach Nigeria decides to take, administrative review or judicial appeal, as argued in Part III $(\mathrm{H})$, the initiation of the relevant procedure should suspend the order of expulsion pending the outcome of the review or appeal.

\section{CONCLUSION}

Over the last years, the phenomenon of statelessness has attracted particular attention, perhaps in the light of the strong connection between statelessness and irregular immigration. 146 Yet neither of the two UN Statelessness Conventions places an explicit obligation on contracting states to establish a statelessness determination procedure. However, it is widely agreed that it is impossible to effectively implement many of the provisions of these conventions without having

140 See UK Immigration Rules (n 136) appendix AR [AR2.3].

141 We would advise that an SDP system to allow self-auditing or external auditing of negative decisions.

142 See Moldova Foreigners Regime (n 110) arts $87^{8}(2), 87^{9}(3)$.

143 Nigerian Constitution (n 113) s 251(1)(i) provides inter alia that "the Federal High Court shall have and exercise jurisdiction to the exclusion of any other court in civil causes and matters' relating to 'citizenship, naturalisation and aliens, deportation of persons who are not citizens of Nigeria, extradition, immigration into and emigration from Nigeria, passports and visas.' The Federal High Court is the only competent court in Nigeria to entertain issues of citizenship, naturalisation and other immigration matters in Nigeria. The court is a central court but with divisions in each of the 36 States of Nigeria.

144 ENS Statelessness Index Survey: France (Report, European Network on Statelessness March 2019)

$<$ https://index.statelessness.eu/sites/statelessindex.eu/files/ENS_Statelessness_Index_Surve y-France-2018.pdf $>$. See also the French Public Administration website on appeals to administrative judge: 'Apatride: titre de séjour, document de voyage' [Stateless Persons: Residence Permit, Travel Document], Service-Public (Web Page) <https://www.servicepublic.fr/particuliers/vosdroits/F15402>.

145 For more information, see 'Apatridie: Les voies de recours', Office français de protection des réfugiés et apatrides [French Office for the Protection of Refugees and Stateless Persons] (Web Page) <https://www.ofpra.gouv.fr/fr/apatridie/les-voies-de-recours>.

146 Konstantina Keramitsi, 'Addressing Statelessness in Greece under EU Law' (PhD Thesis, University of Macedonia, 2019) $6<$ http://www.lse.ac.uk/HellenicObservatory/Assets/Documents/HO-PhD-Symposia/The-9th-HO-PhDSymposium/Symposium-Papers/Session-1/Migration-I-Security.pdf $>$. 
a mechanism for the identification of their beneficiaries. ${ }^{147}$ While for many decades, states have granted refugee status through refugee status determination procedures, a similar commitment is required to develop SDPs.

In this article, we have put forward a number of conditions that SDPs should meet, and we applied these conditions to Nigeria, which is in the process of developing an SDP. We conclude that Nigeria, and in fact any state which has or does not yet have an SDP, may want to give particular attention to standards relating to legality and 'bindingness' of the proposed SDP, to procedural access and to procedural guarantees. SDPs meeting these criteria will make a significant contribution to the protection, identification, prevention and eradication of statelessness worldwide. It remains that bespoke SDP procedures ought to be developed for individual states, as the effectiveness of such procedures depends on their embeddedness in, and relationship to existing institutions. In this article, we have suggested some tailor-made solutions for Nigeria in this respect.

147 Swider and den Heijer (n 12) 109. 